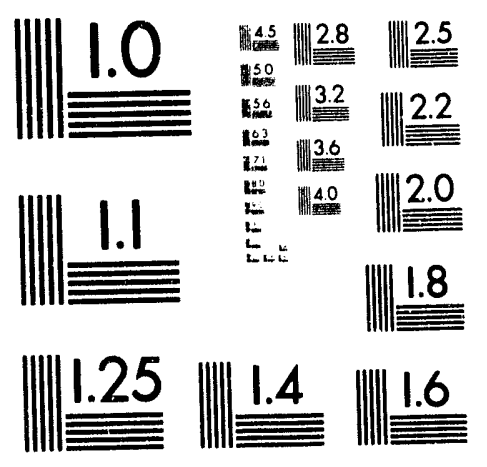



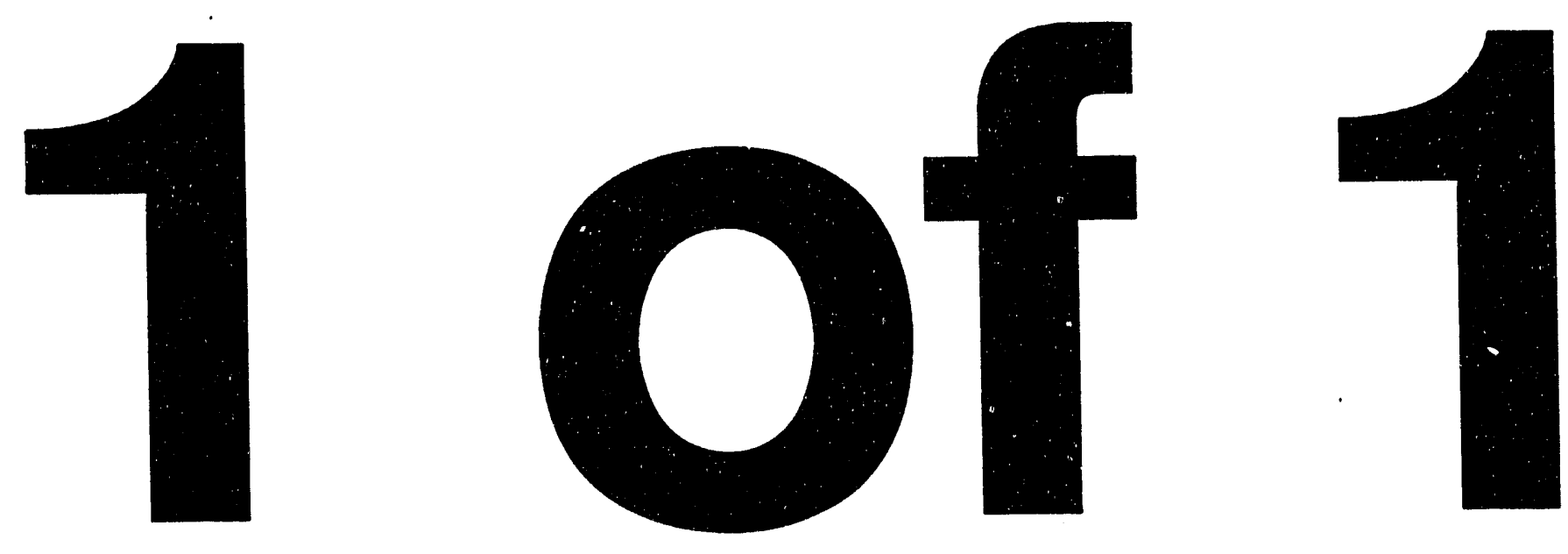


\title{
FAST-ION DIFFUSION MEASUREMENTS FROM RADIAL TRITON BURN UP STUDIES
}

\author{
J. Scott McCauley, R. Budny, D. McCune, and J.D. Strachan \\ Princeton Plasma Physics Laboratory. Princeton University \\ Princeton. NJ 08543
}

A fast-ion diffusion coefficient of $0.1 \pm 0.1 \mathrm{~m}^{2} \mathrm{~s}^{-1}$ has been deduced from the triton Durnup neutron emission profile measured by a collimated array of helium- 4 spectrometers. The experiment was performed with high-power deuterium discharges produced by Princeton University's Tokamak Fusion Test Reactor (TFTR). The fast ions monitored were the 1.0 $\mathrm{MeV}$ tritons produced from the $\mathrm{d}(\mathrm{d}, \mathrm{t}) \mathrm{p}$. These tritons "burn up" with deuterons and emit a $14 \mathrm{MeV}$ neutron by the $\mathrm{d}(\mathrm{t}, \alpha) \mathrm{n}$ reaction. The ratio of the measured to calculated DT yield is typically $70 \%$. The measured DT profile width is comparable to that predicted by the TRANSP transport code during neutral beam heating and narrower after the beam heating ended. 


\section{INTRODUCTION}

The transport of $\mathrm{MeV}$ ions is an important topic in the design of a reactor since a reactor will be heated by $\mathrm{MeV}$ alphas. The behavior of the $\mathrm{MeV}$ ions can be parameterized by their slowing-down time. $\tau_{s}$, and their confinement time, $\tau_{p}$ (which if governed by diffusion is described by a diffusion coefficient

$$
D \approx \frac{a^{2}}{4 \tau_{p}} .
$$

where $\mathrm{a}$ is the minor radius of the torus). For alpha heating to be effective and for the heat load on the first-wall materials from escaping alphas to be manageable. $D$ has to be less than about $2 \mathrm{~m}^{2} \mathrm{~s}^{-1}[1]$.

The $d(d, t) p$ reaction in deuterium plasmas provides a source of $1.0 \mathrm{MeV}$ tritons in a deuterium dishcarge. The birth profile of these fast ions can be deduced by measurement of the 2.45 neutron profile from the $d(d, n)^{3} \mathrm{He}$ reaction and calculation of the birth orbits. Some of the tritons will fuse with deuterons via the $\mathrm{d}(\mathrm{t}, \alpha) \mathrm{n}$ reaction, and this paper reports measurements of the $14 \mathrm{MeV}$ neutron emission profile on TFTR. The $14 \mathrm{MeV}$ neutron emission was compared with TRANSP calculations to determine the possible effects of $\mathrm{MeV}$. ion transport. Comparison of the measured to calculated DT yields indicates that during the beam heating the tritons may have $D=0.1 \pm 0.1 \mathrm{~m}^{2} / \mathrm{sec}$, and that the profile width is comparable to the birth width. After the beam heating ends, the DT emission and width are less than calculated by TRANSP. 


\section{EXPERIMENTAL RESULTS}

The $14 \mathrm{MeV}$ neutron emission was measured by an array of helium- 4 detectors [2.3]. This system is capable of measuring the $14 \mathrm{MeV}$ neutron emission from TFTR at four majorradial locations. The detector was cross-calibrated to $\mathrm{ZnS}$ detectors [4] located in the same neutron flight paths. The cross-calibration occurred during the period from $400-700 \mathrm{~ms}$ after neutral-beam injection when the DT neutron production is dominant. The uncertainty in the absolute calibration of each channel is about $30 \%$. The source strength measurement is computed largely on the basis of the two central detectors (that see the most flux) and the resultant uncertainty in determination of the total source strength is $\approx 20 \%$. Count-rate statistics also are important. The DT flux has to be above $1 \times 10^{15}$ neutrons $\mathrm{s}^{-1} \mathrm{~m}^{-2}$ for the statistical noise to be the same order as the calibration uncertainty. The error in determining the full-width at half-maximum, $\Gamma$, is about $10 \mathrm{~cm}$ for shots above $1 \times 10^{15}$ neutrons $\mathrm{s}^{-1} \mathrm{~m}^{-2}$.

The best helium-4 detector data obtained on TFTR has been obtained by adding together ten similar shots with 1.4 MA, 5.2 Tesla, and $20 \mathrm{MW}$. One of the shots has been modeled by TRANSP. Figure 1 plots the average waveforms of the 10 shot overlaid on top of the same waveforms for the TRANSP shot. As a result. useful helium- 4 data was obtained with $50 \mathrm{~ms}$ resolution (Fig. 2). The DT fluxes in each channel are within a factor-of-two of the TRANSP calculation from 3.0-3.5 s. From 3-4 s, the agreement between the measured and calculated fluxes on \#.5 and \#6 is about $20 \%$. The statistics on the outer two detectors are poorer (uncertainty $\approx 50 \%$ ) but the measured DT flux agrees in magnitude with the TRANSP results. After $4 \mathrm{~s}$, the measured DT flux differs from the calculated flux and the triton population decreases at a faster rate than TRANSP calculated. 


\section{TRANSP CODE}

The transport code TRANSP was developed at the Princeton Plasma Physics Laboratory to study the dynamic transport of plasma species $[\tilde{j}-\tau]$. TRANSP uses experimental data to deduce information that is not directly measured. For example. the deuteron density, $\mathrm{n}_{D}$. is deduced from the electron density and depletion based on $Z_{\text {eff }}$ (visible bremsstrahlung). In a similar way, the magnetic flux surface geometry is determined from the magnetics measurements. the current profile which is computed by solving the poloidal field diffusion equation. and the plasma pressure profile. Resistivity for the poloidal field diffusion equation is deduced from the measured electron temperature profile. Plasma pressure is deduced from electron density measurements. $Z_{\text {eff }}$ measurements. and simulations for fast-ion species.

A key feature of TRANSP is its ability to simulate the observed DD nevitron emission from models of the ion distribution functions as a function of time. velocity, and position. The code has recently been expanded to simulate the behavior of $\mathrm{MeV}$ ion fusion products. A Monte Carlo technique is used in the calculation of triton burnup. The triton source distribution is calculated from the sum of thermonuclear, beam-target. and beam-bearn $d(d, t) p$ reaction rates in the models. The distribution of the birth tritons in velocity space is assumed isotropic to simplify the calculation. The confined fraction is computed by integration of fast triton orbits. The slowing-down and fusion of each sample triton is tracked. To perform this calculation, TRANSP uses the measured electron temperature, the modeled fast deuteron distribution function. modeled thermal ion species, and flat $\mathrm{Z}_{\text {eff }}$ profile. Charge exchange of tritons with neutral atoms in the plasma are calculated as are the effects of sawteeth on the fast ions.

The resultant DT neutron emissivity can then be mapped from magnetic flux surfaces 
into the collimator geometry and chord-integrated to produce a DT radial profile flux as a function of time for comparison the helium- -4 detector data.

Using the TRANSP calculated major radius of the peak DT emission (Fig. 3) and fitting the helium- 4 data to a Gaussian allows determination of the total DT emission, $S_{D T}$, and the width, $\Gamma_{D T}$, of the emission profile with $50 \mathrm{~ms}$ time resolution (Figs. 3 and 4 ). The radial profiles can also be compared in $100 \mathrm{~ms}$ intervals (Fig. 5). There is good agreement (Fig. 2) prior to $4.2 \mathrm{~s}$ between the TRANSP calculations and the measured profile and magnitude of the $14 \mathrm{MeV}$ neutron emission.

After $4.2 \mathrm{sec}$. the $14 \mathrm{MeV}$ neutron emission is about three times less than calculated by TRANSP (Fig. 4). The ${ }^{4}$ He total emission measurements are in agreement with the fission detectors after about $4.4 \mathrm{sec}$ when the $2.5 \mathrm{MeV}$ neutror emission became much smaller than the $14 \mathrm{MeV}$ neutron emission. After $4.2 \mathrm{sec}$, the profile was about $10 \mathrm{~cm}$ narrower than that calculated by TRANSP (Figs. 3 and 5 ).

\section{DISCUSSION}

The data presented in Figs. 3 and 4 differ from TFTR activation measurements of triton burnup measurements [8] made in 1989. The activation data had less than the $1 \%$ burnup yield while some of the helium-4 data are above $1 \%$ (Fig. 6). The helium-4 detector data occurs at higher $\mathrm{T}_{e}$ (longer triton slowing down [9]) and is closer to the expected values than the activation results. Thus, the difference in these burnup measurements from the activation measurements could arise due to diagnostic differences or due to differences in the behavior of the different plasmas that was documented.

A measured-to-calculated burnup ratio of $0 . \bar{\tau}$ corresponds to a $\tau_{s} / \tau_{p}$ ratio of about 0.5 
[10]. Hence. a 0.5 second slowing-down time and measured burnup of $70 \%$ of the classical burnup corresponds tu a triton confinement time of $1 \mathrm{sec}$ and fast ion diffusion coefficient of about $0.1 \mathrm{~m}^{2} \mathrm{~s}^{-2}$. The uncertainty in the diffusion coefficient is also about $0.1 \mathrm{~m}^{2} \mathrm{~s}^{-1}$. largely due to the uncertainties irs the DT neutron yield measurement.

This paper represents the first spatially resolved measurements of triton burnup on TFTR. These measurements were developed ats about the same time as were profile measurements on JET [11]. The reduction in burnup observed at beam turn off in TFTR was not observed on JET. Otherwise. the TFTR DT profile measurements are sirnilar to the JET ones since the DT neutron profile was measured to be $4 \mathrm{~cm}$ wider (about a gyroradius) than the $2.5 \mathrm{MeV}$ emission profile.

Possible explanations for the reduction in triton burnup at $4.2 \mathrm{sec}$ include:

1. The DT emission from $3-4.2 \mathrm{sec}$ is dominated by tritons with energies $>0.5 \mathrm{MeV}$, while after $4.2 \mathrm{sec}$, the burnup is dominated by tritons near the peak of the DT fusion cross-section $(0.1-0.2 \mathrm{MeV})$. Thus. it is possible that the lower energy tritons are being lost all the time.

2. The first sawtooth event occurred at about $4.2 \mathrm{sec}$. There were no sawtooth events during the beam heating. Thus, it is possible that some tritons are lost at the sawtooth. TRANSP can include spatial redistribution of the $\mathrm{MeV}$ ions at the sawtooth over the expected radial extent of the sawtooth. The TRANSP calculation which include triton redistribution at the sawtooth had better agreement with channel \#5 but not \#6 (Fig. 2) and did not significantly change the DT total yield (Fig. 4). Thus, it is possible that the sawtooth could influence the $\mathrm{MeV}$ ions more drastically than a limited spatial redistribution. 
3. The narrowing of the neutron profile after $4.2 \mathrm{sec}$ (Figs. 3 and 5 ) suggest that the $\mathrm{MeV}$ diffusion is larger or the $\mathrm{Z}_{\text {eff }}$ is larger in the larger minor radial locations.

\section{SUMMARY}

Measured triton burnup profiles from the helium-4 detector system were consistent with calculations from TRANSP during neutral beam heating. Analysis of the differences results in a diffusion coefficient estimate of $0.1 \pm 0.1 \mathrm{~m}^{2} \mathrm{~s}^{-1}$. The profiles appear to be static during the neutral beam heating and narrow after the heating is turned off. In the decay phase. the DT neutron emission level is about two to five times below a calculation based upon only first orbit losses of the $\mathrm{MeV}$ tritons.

\section{ACKNOWLEDGMENTS}

This work was supported by U.S. Department of Energy Contract No. DE-AC-02-76CHO-3073. The authors would like to thank K.M. Young for his support, as well as assistance from C.W. Barnes. M. Diesso, J. Felt, L.C. Johnson, H.B. Murphy, and A.L. Roquemore. 


\section{References}

[1] POST. D.E.. et al., ITER Physics. ITER Documentation Series 21, International Atomic Energy Agency, Vienna. 1991.

[2] MCCAULEY. J.S.. and STRACHAN. J.D.. Rev. Sci. Instrum. 63 (1992) 4536.

[3] MCCAULEY, J.S., Measurement and Interpretation of DT Neutron Emission from TFTR, Ph.D. Thesis, Princeton Univesity, 1993.

[4] JOHNSON. L.C.. Rev. Sci. Instrum 63 (1992) 4517.

[5] HAWRYLLK. R.J., An empirical approach to tokamak transport. in Physics of Plasma Close to Thermonuclear Conditions. Brussels, 1980, CEC Vol. 1, pp. 19-46.

[6] GOldSton, R.J., MCCUnE, D.C., TOWNER, H.H. et al., J. Comput. Phys. 43 (1981) 61.

[i] HAWRYLlK, R, et al., Plasma Phys. Controlled Fusion 33 (1991) 1509.

[8] BARNES. C.W. et al., Triton burnup measurements on TFTR. 1992. To be published in Nucl. Fusion.

[9] Batistoni, P. and BARNeS, C.W., Plasma Phys. Controlled Fusion 33 (1991) 1735. Princeton Plasma Physics Laboratory Report No. PPPL-2706. September 1990.

[10] HEIDBRINK W.W., CHRIEN, R.E.. and STRACHAN. J.D.. Nucl. Fusion 23 (1983) 917. 
[11] JARVIS. O.N.. ADAMS. J.M.. CONROY. S.W.. et al.. Triton burnup in JET - profile effects, in Proc. of the 18th European Conference on Controlled Fusion and Plasma Physics. Berlin. 1991. Petit-Lancy, 1991. EPS, Vol. 1, pp. 21-24.

[12] JARVIS. O.N.. SADLER. G., VAN BELLE, P., and ELEVANT. T., Rev. Sci. Instrum $61(1990) 3172$. 
TABLE 1. Integrated Neutron Yields

\begin{tabular}{|l||c||l|l|l|}
\hline Shot & $\frac{Y_{D T . H E 4}}{Y_{D T \text { TRANSP }}}$ & $Y_{\text {DT.He4 }}$ & $Y_{\text {DT.TRANSP }}$ & $Y_{D D}$ \\
\hline \hline 55806 & 0.75 & $3.03+14$ & $4.0 \mathrm{e}+14$ & $2.6770 \mathrm{e}+16$ \\
55804 & 0.84 & $3.4 \mathrm{e}+14$ & $4.0 \mathrm{e}+14$ & $2.6773 \mathrm{e}+16$ \\
558.51 & 0.64 & $2.3 \mathrm{e}+14$ & $3.7 \mathrm{e}+14$ & $2.57293+16$ \\
55606 & 0.81 & $1.5 \mathrm{e}+14$ & $1.9 \mathrm{e}+14$ & $1.4869 \mathrm{e}+16$ \\
55607 & 0.79 & $1.5 \mathrm{e}+14$ & $1.9 \mathrm{e}+14$ & $1.4841 \mathrm{e}+16$ \\
\hline
\end{tabular}




\section{Figures}

Fig. 1. Average waveforms (solid line) for ten similar shots and the shot that had a TRANSP calculation (dashed curve). Each plasma had 5.2 T toroidal magnetic field. 1.4 MA plasma current. and $20 \mathrm{MW}$ neutral beam heating.

Fig. 2. Comparison of the collimated DT fluxes $\Phi_{D T}$, measured by helium-4 detectors (solid line) and calculated by two different TRANSP runs (dotted lines). The lower TRANSP curve incorporates energetic triton redistribution at a sawtooth at $4.2 \mathrm{~s}$.

Fig. 3. Left: Calculation of Plasma Center from TRANSP for the magnetic axis (dashed line) and the center of the DT neutron emission (solid line). Right: Gaussian FWHM prediction by TRANSP (dashed line) and a Gaussian fit to the ${ }^{4} \mathrm{He}$ data (solid line)

Fig. 4. The DT source strength, $\mathrm{S}_{D T}$, for the plasmas of Fig. 1. The solid line is the measurement of the total neutron emission from the fission detectors. The long dashed line is the ${ }^{4} \mathrm{He}$ detector measurement and the short dashed line is the TR.ANSP calculation. The lower TRANSP curve incorporates energetic triton redistribution at the sawtooth at $4.2 \mathrm{~s}$.

Fig. 5. Profiles for the 10 shots. The $y$-axis is the DT emission per area from the volume above the detector, in neutrons $\mathrm{s}^{-1} \mathrm{~m}^{-2}$. The $\mathrm{x}$-axis is the major radius in $\mathrm{cm}$. Dotted curve is fit of TRANSP data (open squares) to a Gaussian. The solid curve is the fit of the helium-4 data (solid diamonds) to a Gaussian using the TRANSP value of the DT neutron emission center. From 3.4-4.1 s (left), the TRANSP FWHM is $48 \mathrm{~cm}$ and helium-4 FWHM is $52 \mathrm{~cm}$. From $4.3-5.0 \mathrm{~s}$ (right), the FWHM's are $40 \mathrm{~cm}$ from TRANSP and $30 \mathrm{~cm}$ from the ${ }^{4} \mathrm{He}$ data. 
Fig. 6. The burnup (DT yield $\mathrm{Y}_{D T}$ divided by the $2.5 \mathrm{MeV}$ neutron yield. $Y_{D D}$ ) as a function cf electron temperature. The + points are activation results from 1989 [8]. The solid diamonds are the ${ }^{4} \mathrm{He}$ measurements. The open squares are TRA.NSP calculations and the solid line is $T_{e}^{1.1}[9]$. 
PPPL\#93X0113

CENTRAL DENSITIES

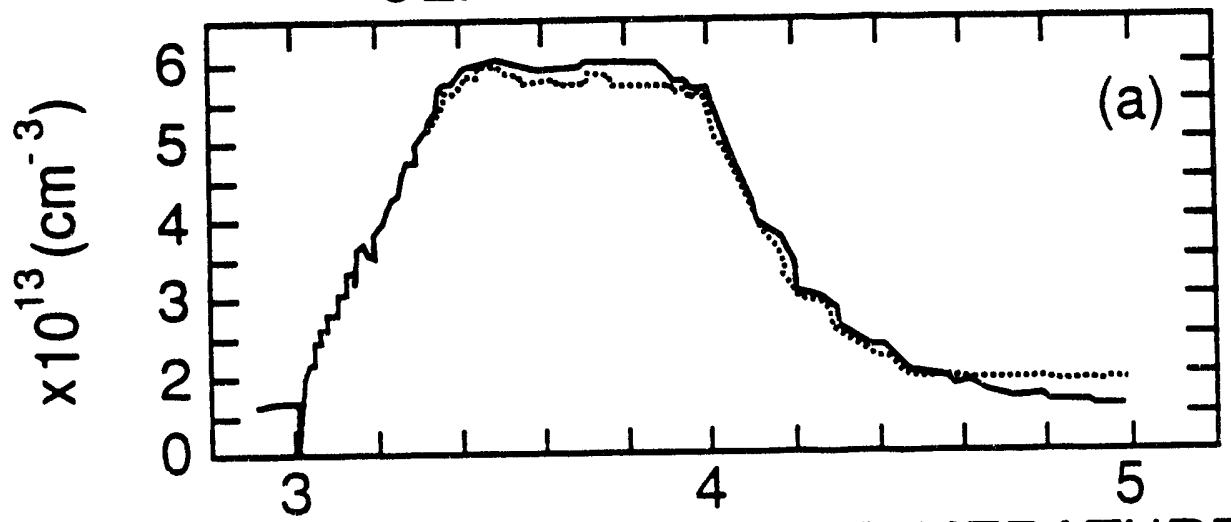

CENTRAL ELECTRON TEMERATURE

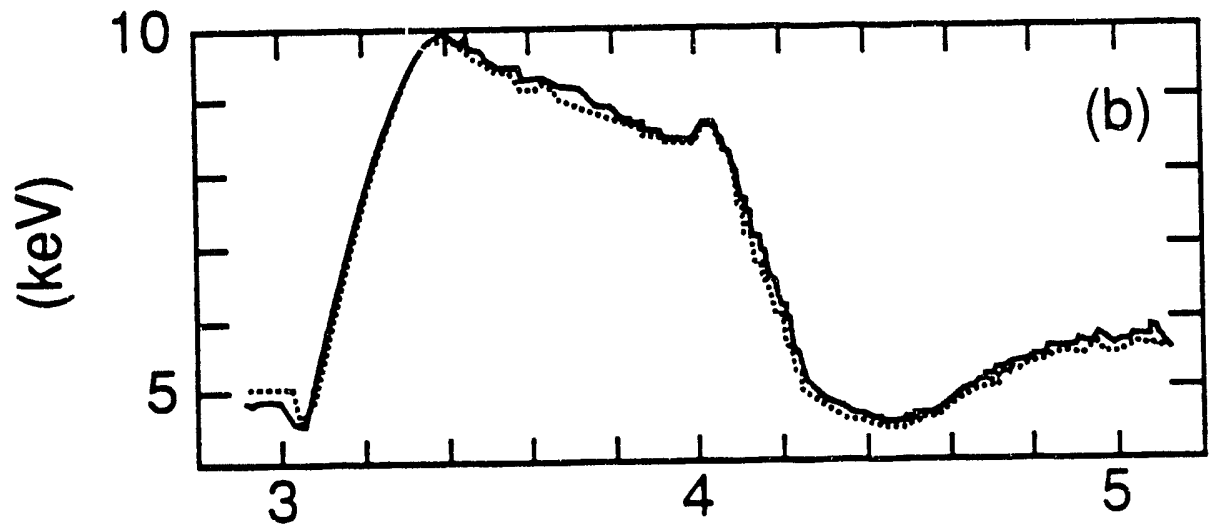

NEUTRON EMISSION

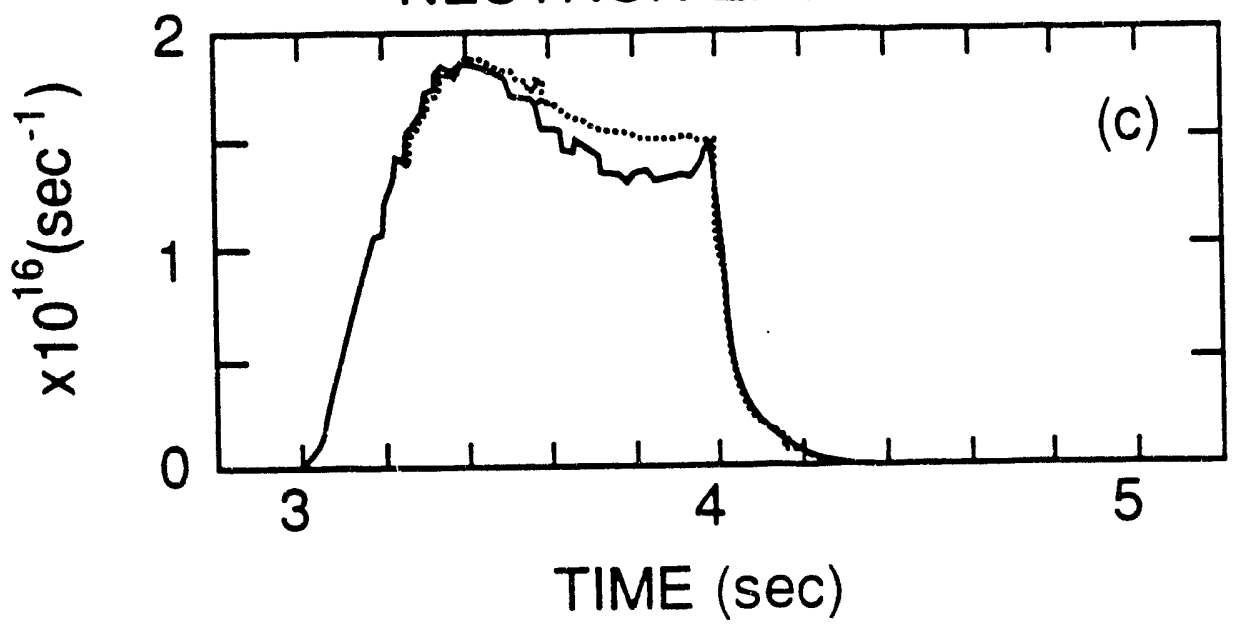

Fig. 1 

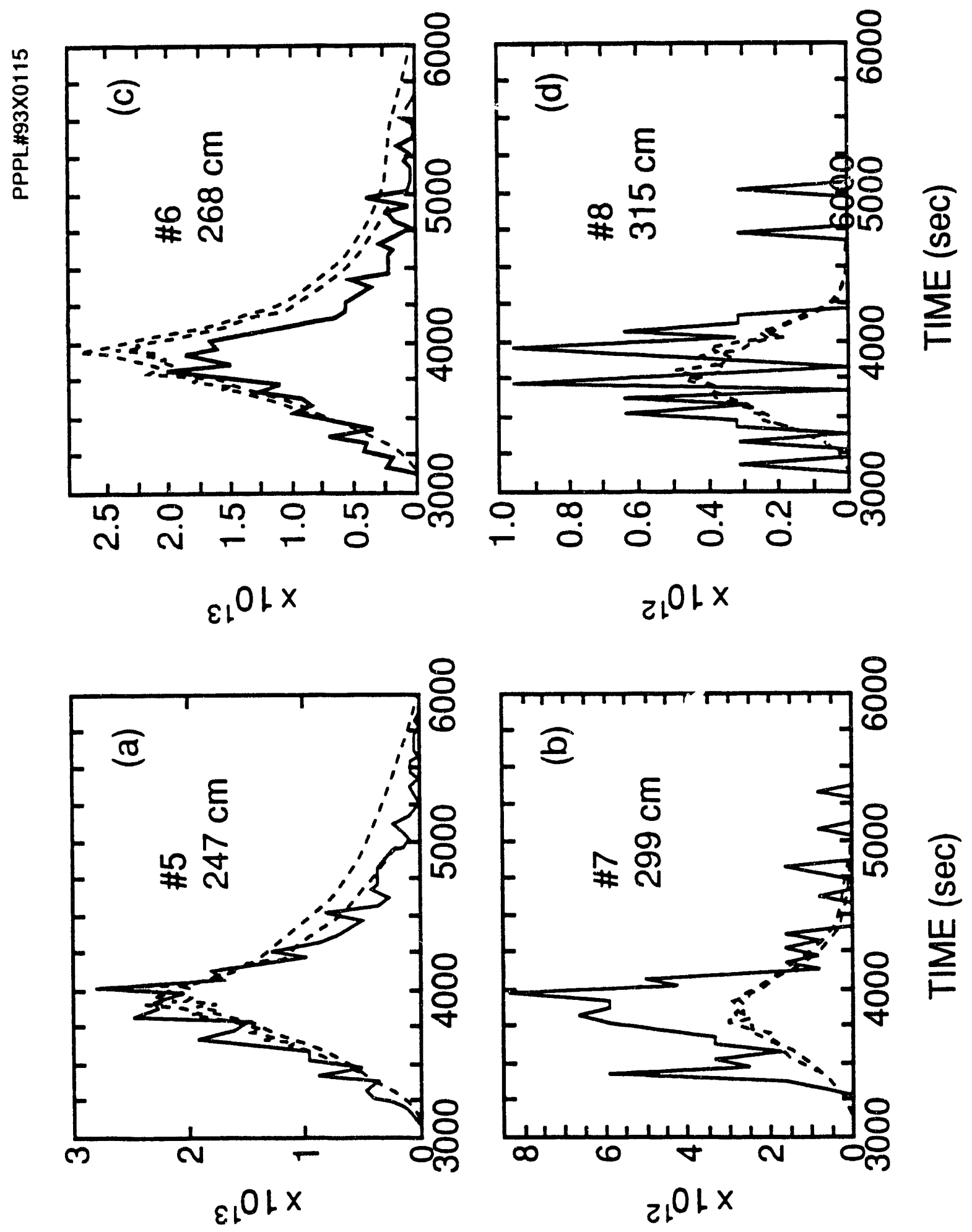

Fig. 2 


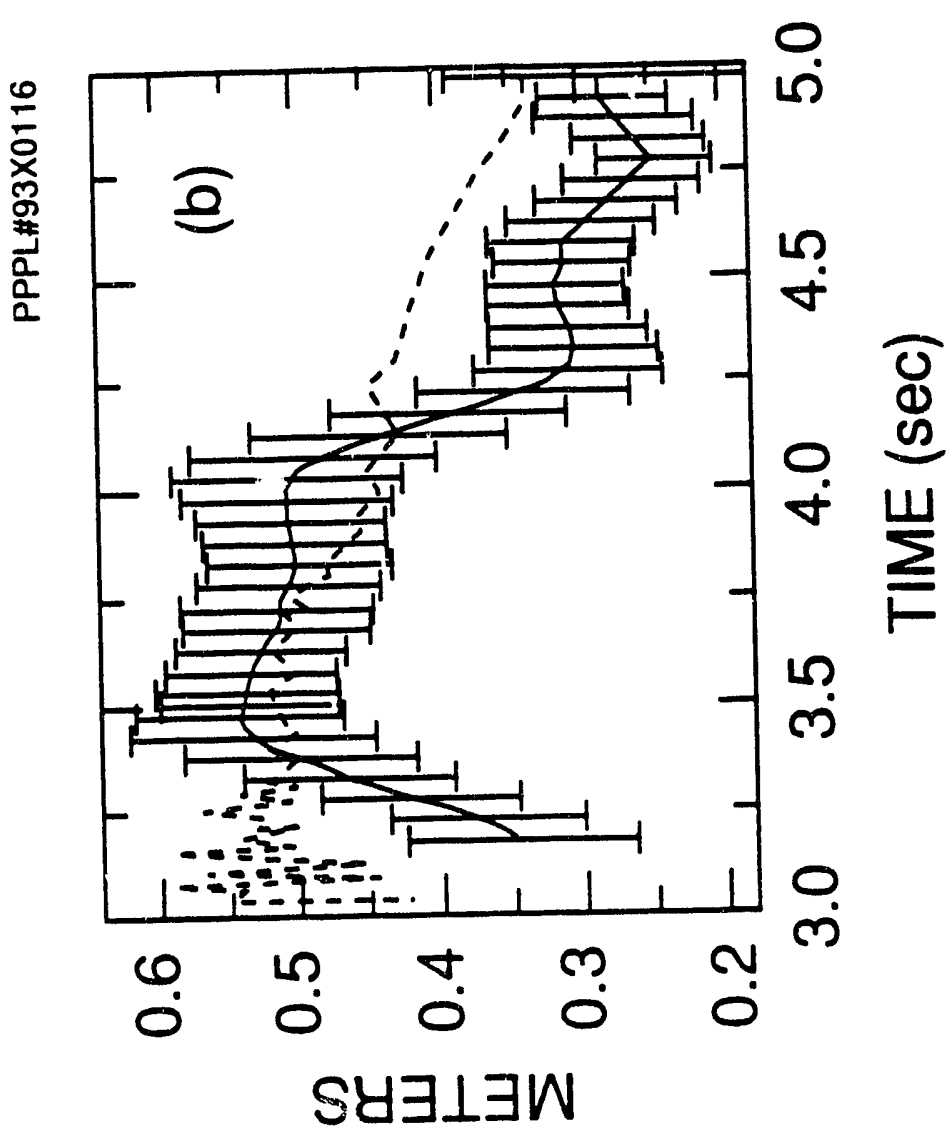

$\underset{m}{m}$

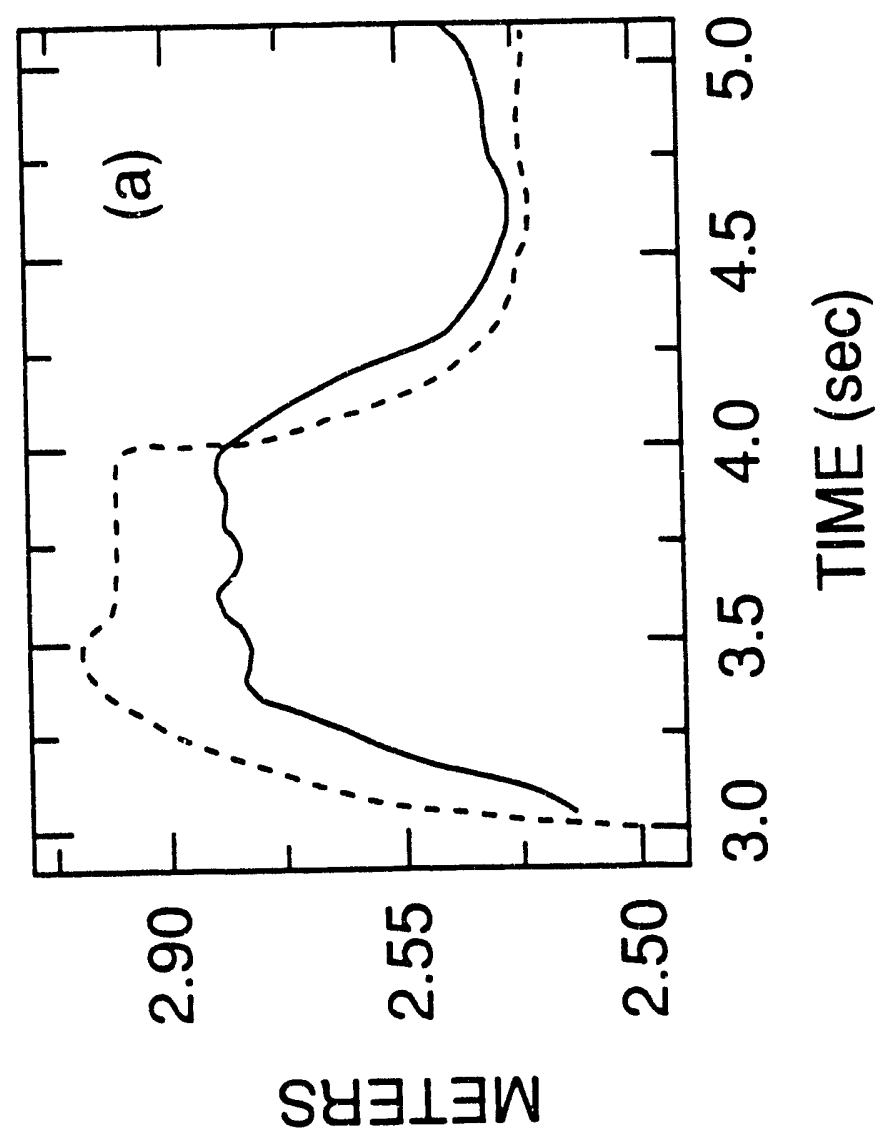


PPPL\#93X0114
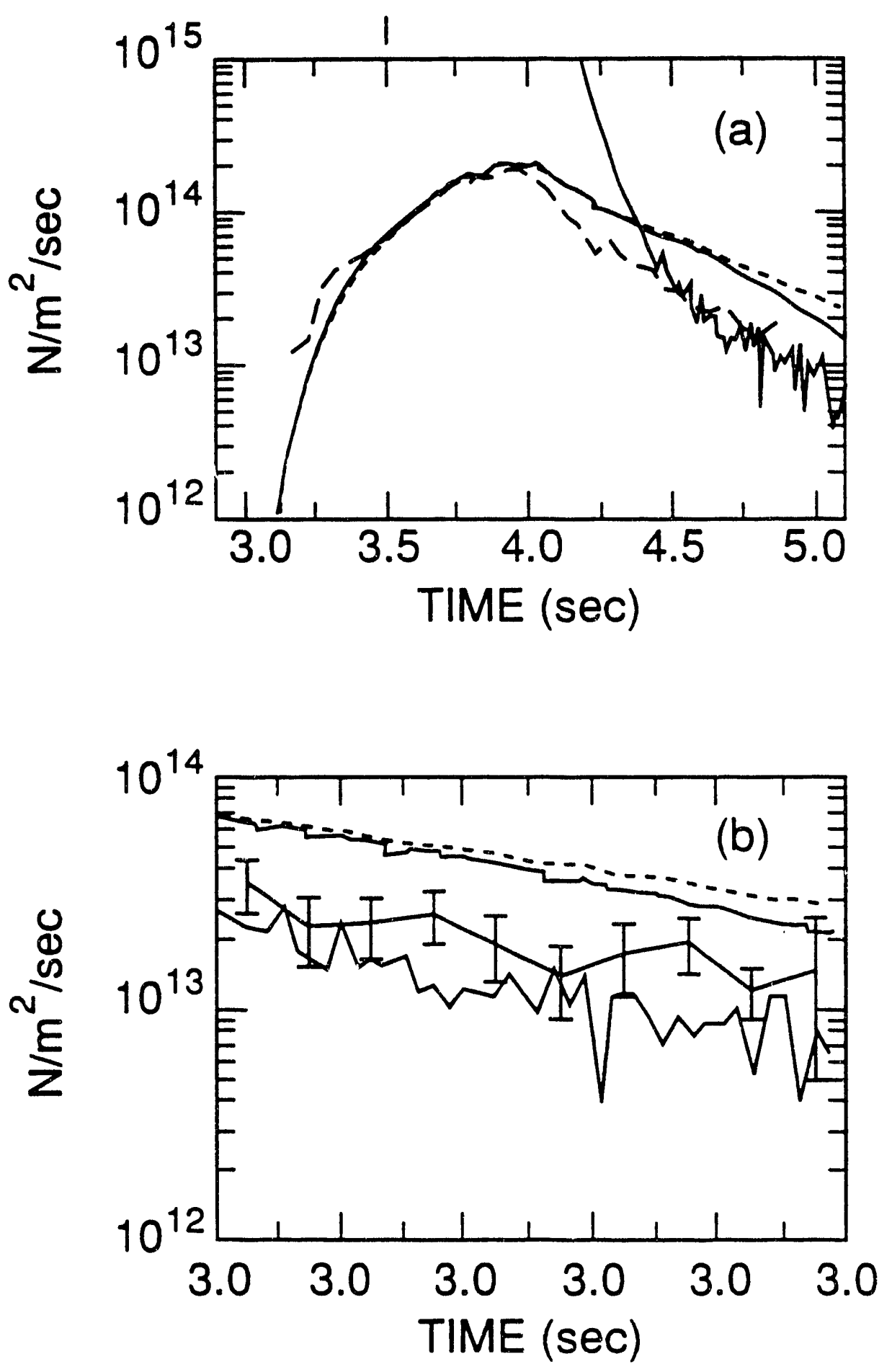

Fig، 4 


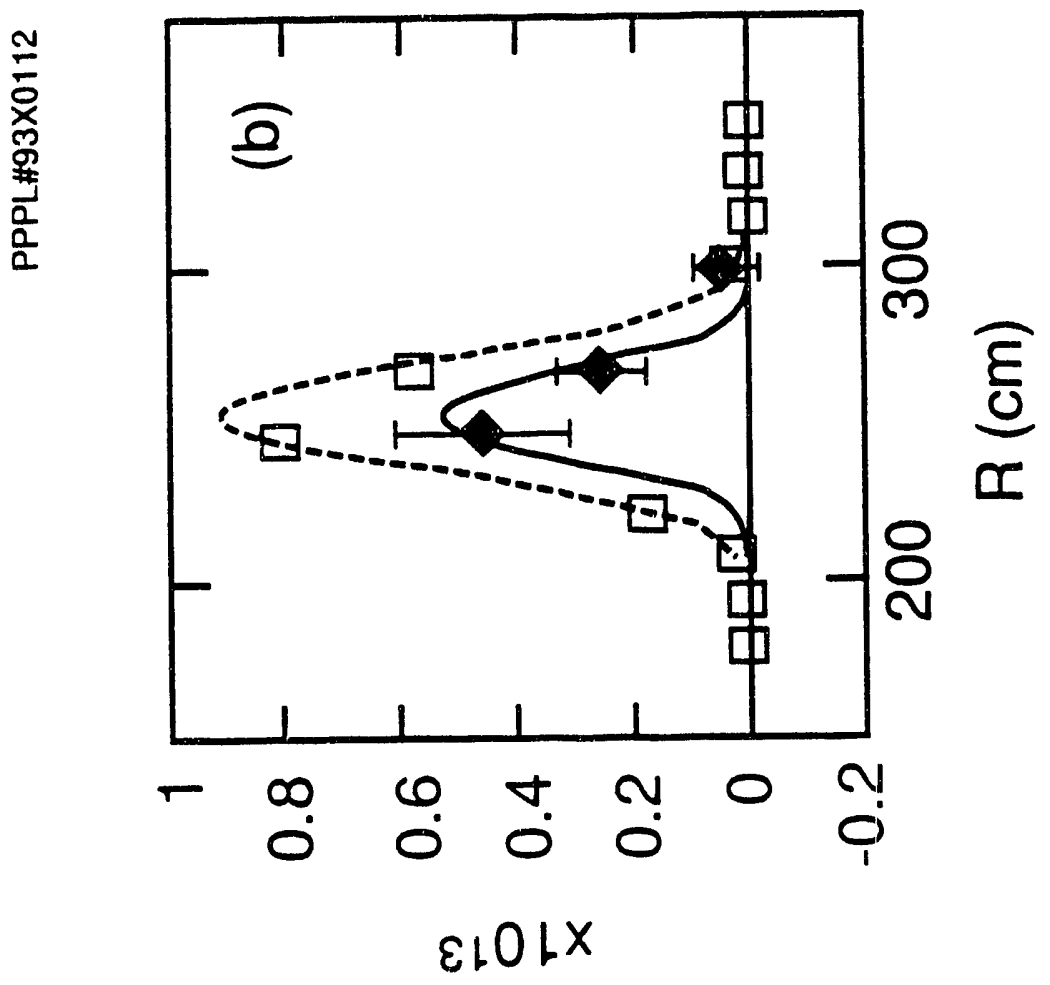

$\underset{\substack{x \\ 0}}{\infty}$

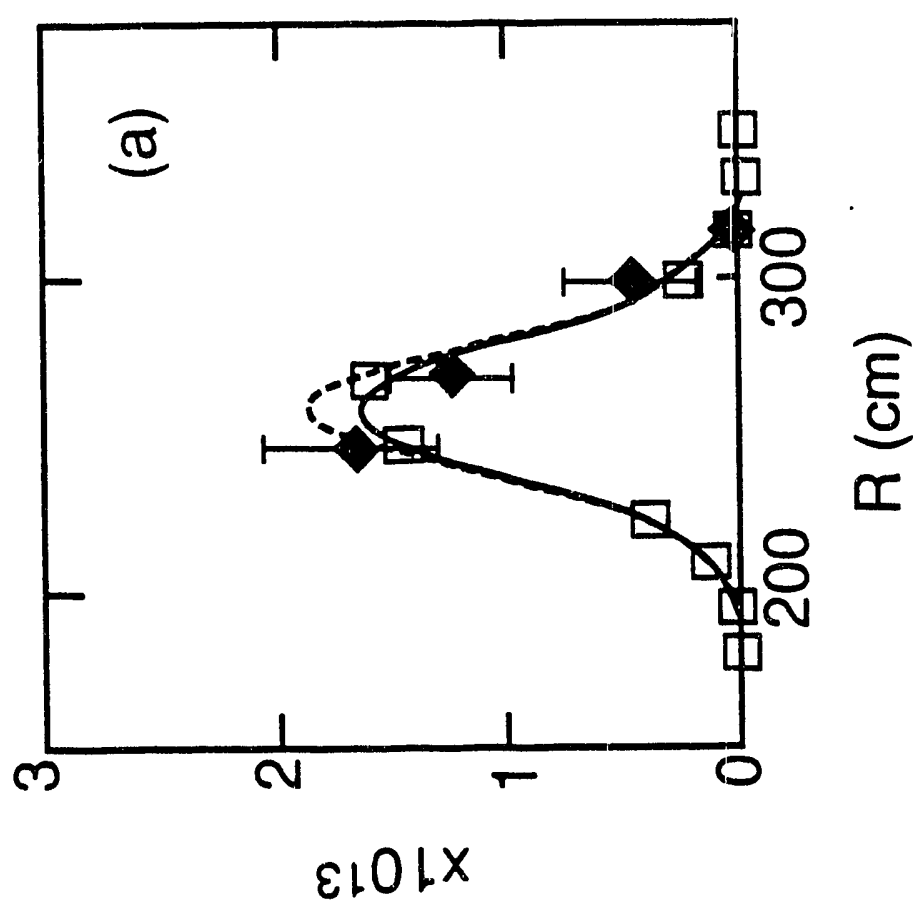




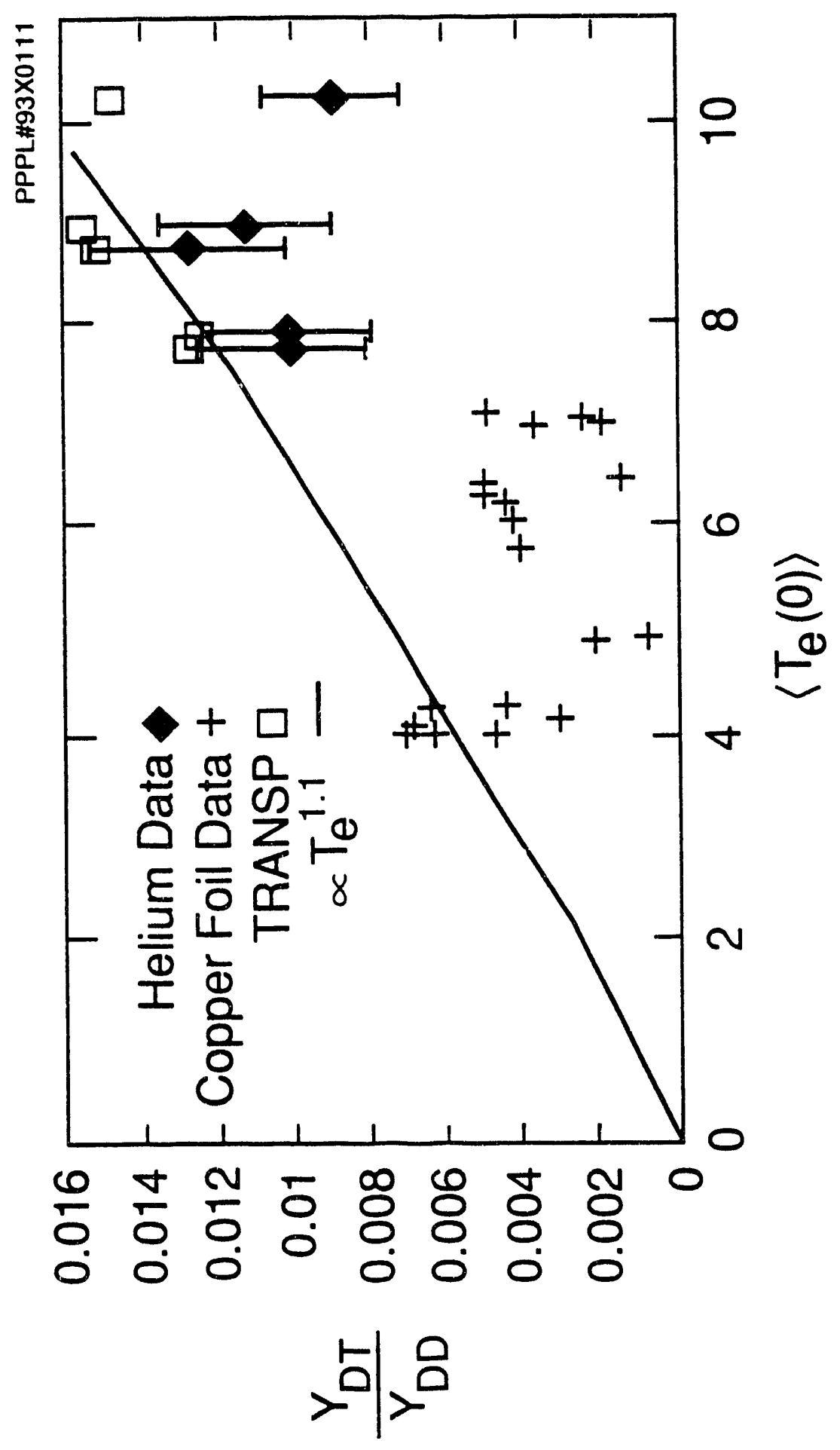


Dr. F. Paoloni, Univ. of Wottongong. AUSTRALIA

Prot. M.H. Brennan, Univ. of Syoney, AUSTRALIA Plasma Rosearch Lob., Australian Nat Univ., AUSTRALIA

Prot. I.R. Jonos, Finders Univ, AUSTRALIA

Prof. F. Cap. Inst for Theoretical Physics, AUSTRIA

Prof. M. Heindter, Instiut far Theoretisctio Physik, AUSTRIA

Prot. M. Goossens, Astronomisch Instituut, BELGIUM

Ecole Royde Msituire, Lob. do Phy. Plasmas, BELGIUM

Commission-Europeen, DG. XII-FUsion Pros., BELGIUM

Prot. R. Bouciqub, Rijksuniveribit Gent, BELGIUM

D. P.H. Sakenaka, Instiuto Frica, BRUZIL

Institus to Neciond Do Poequieas Especisis-INPE. BRUZIL

Doouments Ofico, Abonic Enorgy of Cenedia LId., CANADA

Dr. M.P. Bectynekj, MPB Technologies, Inc., CANADA

Dr. H.M. Skarsagrd, Univ. of Sackatchewan, CANADA

Prol. J. Toictmam, Univ. of Montraal, CANADA

Prof. S.R. Sreenivasen, Univ. of Celgayy, CANADA

Prof. T.W. Johnston, INRS-Energio, CANADA

Dr. C.R. James., Univ. of Nberta, CANADA
Dr. R. Boton, Contro canadion de husion magnévique, CANADA

Dr. P. Lukte, Komonsketho Univorszita, CZECHOSLOVAKIA

The Librarian, Cutham Laborabry, ENGLAND

Librery, R61. Ruthortord Apploton Laboratory. ENGLAND

M. S.A. Hutctinson, JET Libray, ENGLAND

Dr. S.C. Sherme, Univ. of South Pacific, FIJI ISLANDS

P. Mazhonen, Univ. of Helsinki, FINLAND

Prof. M.N. Buseac, Ecole Polytechniouso., FRANCE

C. Noumer, Lob. de Physique des Mulioux tonisós. FRANCE

J. Radel, CENCADARACHE - Bat 506, FRANCE

Prot. E. Economou, Univ. of Crote, GREECE

Ms. C. Rinni, Univ. of loamina, GREECE

Dr. T. Mual, Academy Bibliographic Ser., HONG KONG

Preprint Libray, Hungarian Academy of Sai. HUNGARY

Dr. B Das Gupea, Saha inst of Nuciars Ptrysics, INDIA

Dr. P. Kaw. Inst. tor Plasma Rosoarch, INDIA

Dr. P. Rosenaw, Israel Inst of Tectinology, ISPAEL

Librenan, In mabonal Conter for Theo Ptysics, ITALY

Miss C. De Palo, Associazone EURATOM-ENEA. ITALY

D. G. Grosso, 1505uto di Fisica dol Plasma. ITALY

Prot. G. Rostangni, Is ututo Gas lonizzat Dol Cnr. ITALY

D. H. Yamaro. Tostiba Ros a Devel Centor, JAPAN
Prof. I. Kawakami, Hiroshima Univ., JAPAN

Prot. K. Nishikawa, Hiroshima Univ., JAPAN

Director, Japen Atomic Enorgy Research inst, JAPAN

Prof. S. Itoh, Kyushu Univ., JAPAN

Pesearch Into. Ct. National Instit for Fusion Science, JAPAN

Prof. S. Tanaka, Kyoto Univ., JAPAN

Liorary, Kyoto Univ., JAPAN

Prol. N. Inowe, Univ. of Tokyo, JAPAN

Secrotary, Plasma Section, Electrowochnical Lab., JAPAN

S. Mori, Tectinical Advieor, LAERI, JAPAN

Dr. O. Miterai, Kumamots Inst of Tectinotogy, JAPAN

J. Hyeon-Sook, Korea Alomic Energy Pesearch Inst, KOREA

D.I. Chai, The Korea Adv. Inst of Sai. \& Tech., KOREA

Prol. B.S. Liloy. Univ. of Waikato. NEW ZEALAND

Inst of Physics. Chinese Acad Sai PEOPLE'S REP. OF CHINA

Libray, Inst a Plasma Physics, PEOPLE'S REP. OF CHINA

Tsinghua Univ. Library, PEOPLE'S REPUBLIC OF CHINA

$Z$ L. S.W. Inst Phycica, PEOPLE'S REPUBLC OF CHINA

Prol. J.A.C. Cabred, Instutu Superior Tecnico, PORTUGAL

Dr. O. Porrus, AL I CUZA Univ., ROMANIA

Dr. J. do Villiers, Fusion Studies, AEC, S. AFRICA

Prof. M.A. Hellborg. Univ. of Natal, S. AFRICA

Prot. D.E. Kim, Pohang Inst. of Sa. \& Tech, SO. KOREA

Prot. C.I.E.MA.T, Fusion Division Library, SPAIN

Dr. L Swontio, Univ. of UMEA, SWEDEN

Lorary. Royal Inst. of Tectindogy. SWEDEN

Prof. H. Withotmson. Chaimors Univ, of Tech., SWEDEN

Contro Phys. Des Plasmas. Ecole Polytech. SWITZERLAND

Bibliotheok, Inst. Voor Plasma-Fysica, THE NETHERLANDS

Asst Prot. Dr. S. Cakir, Midde East Tech Univ., TURKEY

Dr. V.A. Gukthikh,Sa. Res. Inst Electrophys.I Apparatus, USSR

D. D.D. Ryubv, Siberian Branch of Academy of Sa., USSR

Dr. G.A. Elisoov, I.V. Kurchatov Inst, USSR

Librarian, The Ukr.SSA Academy of Scroncos, USSA

D. LM. Kovizizmykh, Inst of General Physics, USSR

Komtorsctungsanlage GmbH, Zentralbibliotiek, W GERMANY

Bibliothek, Inst. Fur Plasmatorsctiung. W GERMANY

Prol. K. Sctinder, Ruhr-Universital Bochum, W. GERMANY

D. F. Wogner, (ASOEX), Max-Planck-Instut, W. GERMANY

Lorarian, Max-Planck-Insotur, W. GERMANY

Prot. R.K. Janor, Inst of Ptysics. YUGOSLAVIA 

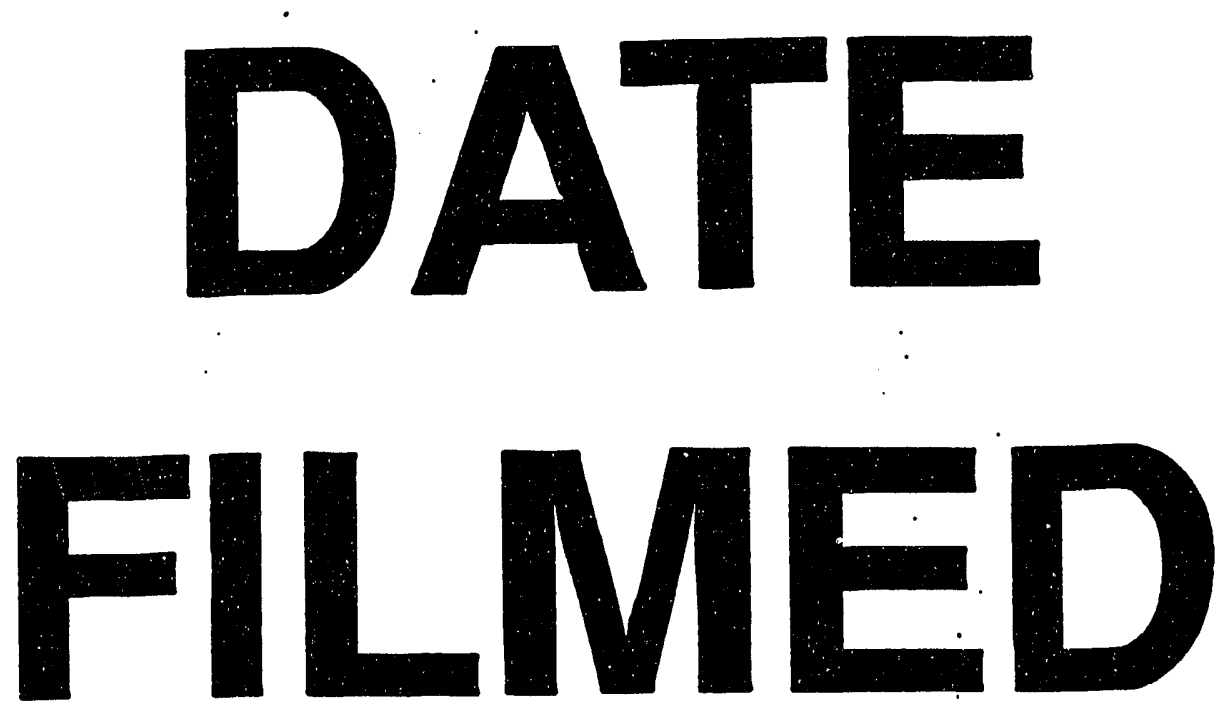

$10 / 20 / 93$
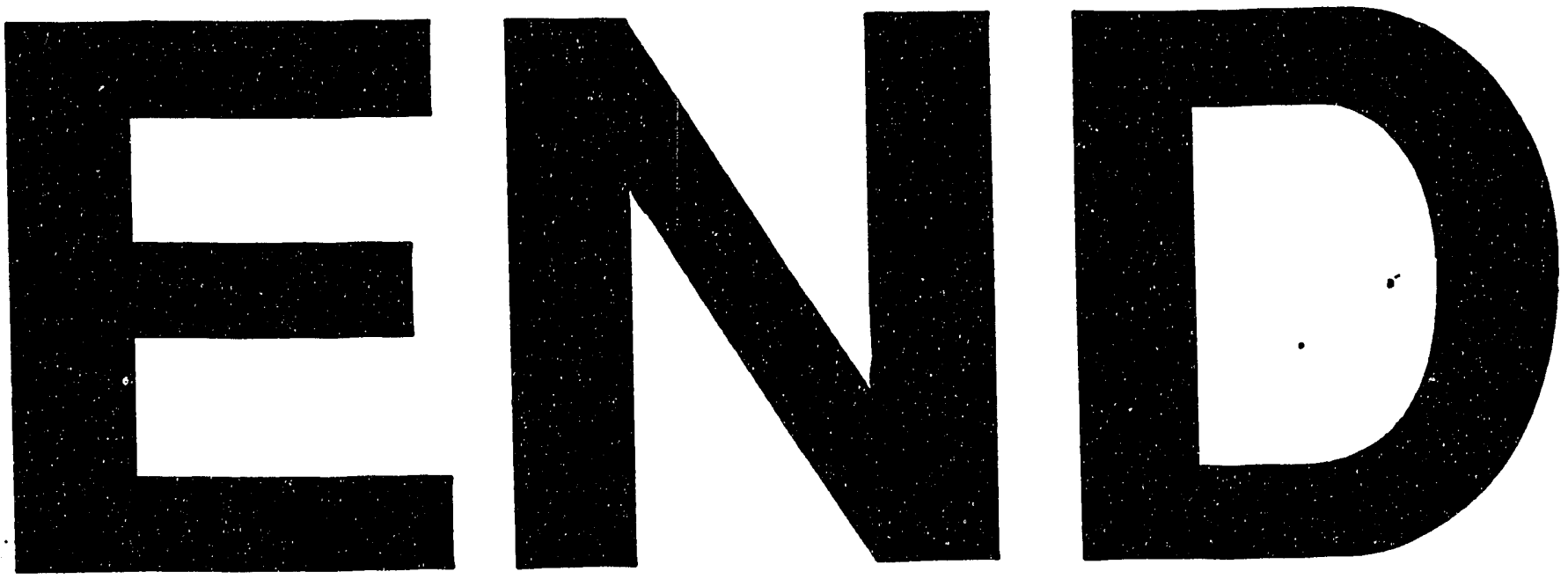
